\title{
Massive open online courses in professional development of Engineering students
}

\author{
Artyom Zubkov ${ }^{1, *}$ \\ ${ }^{1}$ Novosibirsk State Technical University, 630073, 20 K, Marksa ave., Novosibirsk, Russia
}

\begin{abstract}
The article considers the possibilities of using massive open online courses (MOOCs) to build professional competencies of engineering students. Engineering online courses delivered on international educational platforms are studied. The criteria for inclusion of MOOCs in the list of courses recommended for integration into the training of future engineers at university are given. The integration models of these courses are generalised. The positive aspects and difficulties of MOOCs integration are given. It is concluded that MOOCs are efficient for usage in teaching foreign language for specific purposes.
\end{abstract}

\section{Introduction}

\subsection{Research Problem}

In the conditions of information society, global communications and digital educational environment the problem of optimizing and improving the quality of language and professional training of engineering specialists in technical university on the basis of blended instruction is urgent. The latest trends in the development of ICT focus on the development of innovative strategies in education and training. New opportunities for using ICT in education and training increase the students chances to receive their professional qualification.

Universities in Russia are faced with necessity to make decisions about how to meet the various students` needs in the changing education market while fulfilling educational tasks. The traditional model and system of higher education laid down in the Middle Ages is becoming obsolete and massive open online courses (MOOCs) has become today's reality and entered our life.

The concept of the development of MOOCs is based on the ideals of open education, the idea that knowledge should be freely transferred from person to person and the desire to learn should be supported without any demographic, economic or geographical limitations.

The purpose of the study is to assess the possibilities of using MOOCs to develop the professional competencies of engineering students in professional and general disciplines. To do this it is necessary to carry out a comprehensive examination of massive open online courses in order to study the possibility of its usage in educational process of university.

\footnotetext{
* Corresponding author: artemlux@ yandex.ru
} 


\subsection{Literature Review}

As for researchers, certain aspects of this issue are covered in the works of the following researchers who studied motivation and learning in engineering education using gamification in MOOC [1], the impact of MOOCs on engineering education [2], challenges and solutions of massive open online courses in engineering education [3], adopting MOOCs for quality engineering education [4], flipped classroom in engineering education [5], seeking open educational resources to compose massive open online courses in engineering education [6], innovative teaching methods in Engineering [7] and collaborative learning in engineering MOOCs [8].

\subsection{Basic Assumptions}

Massive open online courses have recently attracted close attention of educators and researchers. MOOCs provide free access to the newest courses. The primary goal of MOOCs is to "open up" education and provide free access to higher education for more students from different countries.

Unlike traditional university online courses, MOOCs has the following key features:

- Open access - anyone can become a participant of an online course free of charge;

- Scale - an infinite number of learners can participate in a course;

- Online - all learning materials and products of learners' activities are available on the network in authorized access mode;

- A Course - teaching materials are structured according to author's pedagogical design.

\section{Materials and methods}

The author has studied MOOCs in the following categories: Electrical Engineering, Mechanical Engineering, Chemistry, Ecology and Sustainability and Physics and Astronomy. The courses are designed to meet the academic needs of engineering students and must cover the areas of knowledge of fundamental and professional training of future specialists in different engineering areas.

The following MOOC aggregators were chosen as sources of the primary research material: ClassCentral (https://www.class-central.com/), MOOC list (https://www.mooclist.com/), Learning Advisor (http: // www.learningadvisor.com), Open Education Europa (http://www.openeducationeuropa.eu/), which provide information on the main features of e-courses of the main modern MOOC platforms and providers.

The following inclusion criteria were used during the study:

- MOOCs selected should be designed to build competencies in "Engineering" at level of higher education;

- The titles of MOOCs should clearly contain direction or correspond to the titles of professional disciplines for engineering training areas (Electronics and Nanoelectronics, Instrument-Making, Optotechnics, Biotechnical Systems and Technologies, Heat Engineering, Electrical Power and Electrical Engineering, Nuclear Physics and Technology, Mechanical Engineering, Mechatronics and Robotics, Chemical Technology of Materials, Applied Geology, Ecology etc.);

- Free access to course learning material.

As a result of application of exclusion criteria some MOOCs were not considered. These MOOCs:

- are delivered by MOOC providers with the total number of online courses less than 10;

- do not contain annotations and course information on the start pages;

- designed to improve the skills of teachers and instructors of engineering disciplines. 


\section{Research data}

As a result of MOOC selection only 114 out of 150 MOOCs meet the criteria described above. One of the important attributes of MOOCs is the information about organization and authors of a course. In the development of modern MOOCs both academic institutions and engineering community are involved.

The project-oriented approach is also important for training students in engineering areas of study. In this respect, only $20 \%$ of the courses considered satisfy this condition. Some MOOCs selected for building professional competences to engineering students via blended educational models are presented in the Table 1.

Table 1. Some MOOCs selected for teaching professional disciplines to engineering students.

\begin{tabular}{|c|c|c|}
\hline № & Course title & Developer \\
\hline $\mathrm{C} 1$ & Intro to Acoustics (Part 1) & $\begin{array}{l}\text { Korea Advanced Institute of } \\
\text { Science and Technology }\end{array}$ \\
\hline $\mathrm{C} 2$ & Bioelectricity: A Quantitative Approach & Duke University \\
\hline $\mathrm{C} 3$ & Applications in Engineering Mechanics & $\begin{array}{l}\text { Georgia Institute of } \\
\text { Technology }\end{array}$ \\
\hline $\mathrm{C} 4$ & $\begin{array}{l}\text { Internet of Things Capstone: Build a Mobile } \\
\text { Surveillance System }\end{array}$ & $\begin{array}{l}\text { University of California, San } \\
\text { Diego }\end{array}$ \\
\hline $\mathrm{C} 5$ & Fundamentals of Audio and Music Engineering & University of Rochester \\
\hline C6 & MOS Transistors & Columbia University \\
\hline $\mathrm{C} 7$ & Photovoltaic solar energy & École Polytechnique \\
\hline $\mathrm{C} 8$ & Introduction to solar cells & $\begin{array}{l}\text { Technical University of } \\
\text { Denmark (DTU) }\end{array}$ \\
\hline C9 & Linear Circuits 1: DC Analysis & $\begin{array}{l}\text { Georgia Institute of } \\
\text { Technology }\end{array}$ \\
\hline $\mathrm{C} 10$ & Introduction to FPGA Design for Embedded Systems & $\begin{array}{l}\text { University of Colorado at } \\
\text { Boulder }\end{array}$ \\
\hline $\mathrm{C} 11$ & Interfacing with the Arduino & University of California, Irvine \\
\hline $\mathrm{C} 12$ & Advanced Chemistry & University of Kentucky \\
\hline $\mathrm{C} 13$ & Introduction to Physical Chemistry & The University of Manchester \\
\hline C14 & Materials in Oral Health & The University of Hong Kong \\
\hline $\mathrm{C} 15$ & Statistical Molecular Thermodynamics & University of Minnesota \\
\hline $\mathrm{C} 16$ & Chemicals and Health & Johns Hopkins University \\
\hline $\mathrm{C} 17$ & DNA Decoded & McMaster University \\
\hline $\mathrm{C} 18$ & Material Behavior & $\begin{array}{l}\text { Georgia Institute of } \\
\text { Technology }\end{array}$ \\
\hline C19 & $\begin{array}{l}\text { Introduction to Thermodynamics: Transferring } \\
\text { Energy from Here to There }\end{array}$ & University of Michigan \\
\hline $\mathrm{C} 20$ & Digital Thread: Components & $\begin{array}{l}\text { University at Buffalo, The State } \\
\text { University of New York }\end{array}$ \\
\hline $\mathrm{C} 21$ & Fundamentals of GIS & University of California, Davis \\
\hline $\mathrm{C} 22$ & Marketing Verde & Universidad de Los Andes \\
\hline $\mathrm{C} 23$ & The Age of Sustainable Development & Columbia University \\
\hline $\mathrm{C} 24$ & Greening the Economy: Sustainable Cities & Lund University \\
\hline $\mathrm{C} 25$ & Introduction to Environmental Law and Policy & $\begin{array}{l}\text { University of North Carolina at } \\
\text { Chapel Hill }\end{array}$ \\
\hline $\mathrm{C} 26$ & How Things Work: An Introduction to Physics & University of Virginia \\
\hline $\mathrm{C} 27$ & Particle Physics: an Introduction & University of Geneva \\
\hline $\mathrm{C} 28$ & Astronomy: Exploring Time and Space & The University of Arizona \\
\hline $\mathrm{C} 29$ & Introduction into General Theory of Relativity & Higher School of Economics \\
\hline $\mathrm{C} 30$ & $\begin{array}{l}\text { Mechanics: Motion, Forces, Energy and Gravity, } \\
\text { from Particles to Planets }\end{array}$ & $\begin{array}{l}\text { The University of New South } \\
\text { Wales }\end{array}$ \\
\hline
\end{tabular}


Upon MOOC completion students receive a certificate free of charge signed by the instructors of the corresponding course. Certificate of completion can be used by students in their educational institution for credit transfer and confirmation of competences acquired.

Depending on the aims and training objectives, strategies of educational institution, methods of organizing the studying work of university teachers, modern researchers identify the following models of MOOCs integration into educational process of university:

- Support for MOOC participants - providing educational services to participants of online courses that are not studying at this university (for example using the library);

- MOOC as open educational resources - selective materials of a MOOC are studied in face-to-face courses;

- A flipped class - full-time students use MOOCs for independent work, during each week they work with MOOCs independently, after that they come to the class to fix the material studied;

- MOOC as a basis - the training course is developed on the basis of projects that fulltime students are studying in parallel with MOOC;

- A transfer of MOOC credits - recognition of MOOC results and credits of the educational program after passing the exam [9];

- MOOC as an introductory part - the first part of the course is completely online, then the second part is face-to-face;

- Distance learning with full-time consultations - students use MOOC materials independently to prepare for the exam, face-to-face classes are not available, but hours for consultations with a teacher are allocated;

- Distance learning with online consultations - MOOC is studied by students fully, a teacher consults group of students online;

- MOOC as a textbook - MOOC is used as the only resource in the face-to-face course [10].

\section{Language diversity of MOOCs selected}

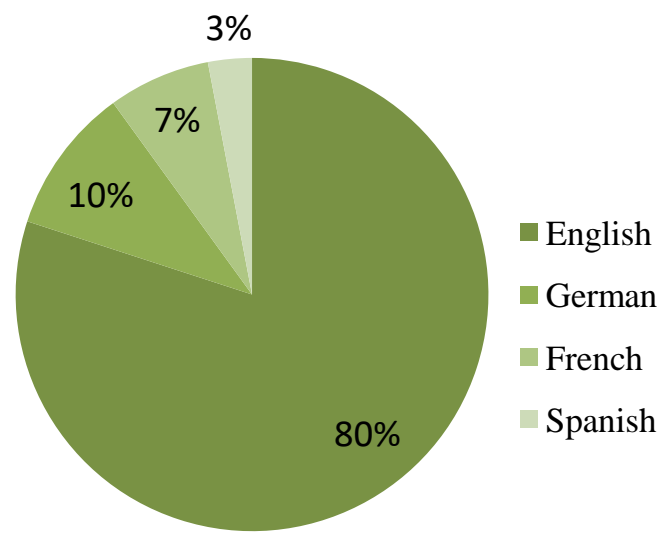

Fig. 1. Language diversity of MOOCs selected.

Analysis of the list of MOOCs selected showed that content of online courses is implemented in 4 languages (English, French, German, Spanish). The result of MOOC clustering according to the language principle is presented in the form of pie chart (Fig. 1). These results make it possible to use subject MOOCs as a resource for teaching foreign language for specific purposes (LSP) in university. 
The introduction of MOOCs into the practice of teaching engineering disciplines has a number of positive aspects:

- Richness and diversity of authentic professionally directed learning material;

- Understandable structure and clear evaluation system;

- Increase of students` motivation and independence, expansion of professional horizons;

- Integration into the world academic community as an additional stimulus to study foreign languages;

- A combination of listening, reading and writing within the same format and connecting the talk at the stage of group and individual work contributing to the complex development of skills for these activities (while teaching language for specific purposes);

Among the difficulties that need to be overcome it can be noted the following:

- Inconsistency of the MOOCs proposed and higher institution curriculum;

- Impossibility of long-term planning due to unpredictable availability of courses;

- Impossibility of working with courses at the expert level without involving instructors from subjects departments.

\section{Conclusion}

In conclusion, it is noted that despite the many questions that arise on the way of implementing MOOCs in engineering education, it is possible to see great potential in this format of work and a high level of students interest in blended educational formats based on modern information and communication technologies. The use of MOOCs in the educational process helps to solve various educational and academic problems. Integration of MOOCs into full-time courses at tertiary level is a new educational format. Online courses act as a powerful resource that can complement traditional forms of higher education teaching. Such integration allows to optimize the educational process, supplement the full-time course with quality material, improve the students' subject, foreign-language and communicative competencies. Among the many advantages of introducing blended and e-learning technologies, it is necessary to distinguish the possibilities of an extensive selection of teaching materials, pedagogical methods and techniques. The introduction of subject MOOCs in the courses of teaching academic and professional communication in foreign language at an advanced level of training graduate and postgraduate students is especially promising.

\section{References}

1. O. Borras-Gene, M. Martinez-Nuñez, Á. F. Blanco, IJEE, 32, 507 (2016)

2. X. Zhu, Y. Chen, Z. Jie, IEEE MITE, 512 (2014)

3. L. Stuchlíková, A. Kósa, IEEE 11th International Conference on Emerging eLearning Technologies and Applications (ICETA), 361 (2013)

4. B. Phatak, Deepak. Adopting MOOCs for Quality Engineering Education in India (2015)

5. B. Kerr, Interactive Collaborative Learning, 301 (2015)

6. P. N. Chicaiza, J. L. Tovar, JUCS, 21 (2015)

7. F. García-Peñalvo, R. Colomo-Palacios, IJEE, 31 (2015)

8. W. Billingsley, J. H. Steel, Companion Proceedings of the 36th International Conference on Software Engineering, 284 (2014) 
9. W. I. Demeulenaere, Beyond the language classroom: researching MOOCs and other innovations (2016)

10. K. C. Delgado, P. J. Muñoz-Merino, C. Alario-Hoyos, I. E. Ayres, Proceedings of the IEEE Global Engineering Education Conference (EDUCON), 969 (2015) 